\title{
Element Redistribution along Hydraulic and Redox Gradients of Low-Centered Polygons, Lena Delta, Northern Siberia
}

\author{
S. Fiedler,* D. Wagner, L. Kutzbach, and E.-M. Pfeiffer
}

\begin{abstract}
Wetland soils affected by permafrost are extensive in subarctic and arctic tundra. However, this fact does not imply these soils have been sufficiently investigated. In particular, studies of element translocation processes are scarce. This study was conducted (i) to determine the relationship between water and redox regimes in wetland soils in the Siberian tundra, and (ii) to investigate their influence on the distribution of redox sensitive and associate elements ( $\mathrm{Mn}, \mathrm{Fe}, \mathrm{P}$ ). Major geomorphic units were chosen (microhigh, polygon rim and slope; microlow, polygon center) from two low-centered polygons in the Lena Delta. Within polygons, redox potential, permafrost, and water level were measured during summer in 1999 and 2000 and (related) compared with element distribution. Manganese, $\mathrm{Fe}$, and $\mathrm{P}$ accumulations were preferentially observed in aerobic microhighs. Anaerobic conditions in the microlows lead to a mobilization of $\mathrm{Mn}$, $\mathrm{Fe}$, and $\mathrm{P}$. The elements migrate via water and are immobilized at the microhigh, which acts as an oxidative barrier. The element pattern, indicating an upward flux via water along redox gradients, is explained by higher evapotranspiration from soils and vegetation of the microhighs (Typic Aquiturbel) compared with soils and vegetation of the microlows (Typic Historthel). However, in further research this upward transport should be validated using labeled elements.
\end{abstract}

$\mathrm{S}^{\mathrm{o}}$ ILS IN SUBARCTIC and arctic tundra affected by permafrost occupy a total area of $1.5 \times 10^{9} \mathrm{~km}^{2}$ (Harris et al., 1993). Permafrost soils represent the largest group of natural wetlands, which are an important source of the greenhouse gases methane and carbon dioxide (Aselmann and Crutzen, 1989; Christensen et al., 1995). They are C sinks (Bliss, 1997) as well, storing about $30 \%$ of the global soil organic C (SOC) (Michaelson et al., 1996). With respect to the predicted global temperature increase, it is assumed these soils can switch from sinks to sources of C (Grulke et al., 1990; Oechel et al., 1993). Therefore, recent studies primarily deal with $C$ budgets, especially with the microbial processes of methane production and methane oxidation (Wagner et al., 2001a, 2003). In addition, permafrost soils are of special interest for current astrobiological research. Permafrost areas and the Mars surface have shown similar morphological structures, which suggest their development is based on comparable processes (Wagner et al., 2001b). The typical patterned ground in permafrost regions is composed of recurrent symmetrically formed ice wedge polygons that have emerged from annual freeze-thaw

S. Fiedler, Univ. of Hohenheim, Inst. of Soil Science and Land Evaluation, D-70593 Stuttgart, Germany; D. Wagner, and L. Kutzbach, Alfred Wegener Institute, Foundation for Polar and Marine Research, Telegrafenberg A43, 14473 Potsdam, Germany; E.-M. Pfeiffer, Institute of Soil Science, Allende-Platz 2, 20146 Hamburg, Germany. Received 31 Dec. 2002. *Corresponding author (fiedler@uni-hohenheim.de).

Published in Soil Sci. Soc. Am. J. 68:1002-1011 (2004).

(c) Soil Science Society of America

677 S. Segoe Rd., Madison, WI 53711 USA processes (Brown, 1967; Tedrow, 1977; Tarnocai and Zoltai, 1978; Washburn, 1979). During winter, ice wedges crack, releasing contraction tension. During spring, melt water seeps into these cracks, eventually freezing and continuing the process. Expansion of the surface layer is caused by increasing surface temperatures during summer, which leads to a typical microrelief. Some parts are elevated (polygon rim and slope $=$ microhigh), whereas others are depressed (polygon center $=$ microlow). Upturning of permafrost strata by plastic deformation leads to transport of the solid soil phase. This process is reflected by twisted and mixed soil horizons as well as buried organic matter (Bockheim and Tarnocai, 1998) (Fig. 1). It is generally agreed cryoturbation is the dominant pedogenetic process of the polar regions (Van Vliet-Lanoë, 1991; Bockheim et al., 1999, 2003). However, in addition to twisted layers, continuous bands of Fe can also be found. These features follow the buckling surface regularly and indicate element transport via liquid phase is an important pedogenetic process within the polygons (Fig. 1).

Although arctic studies have added to an understanding of arctic soils (Feustel et al., 1939; Tedrow et al., 1958; Gersper et al., 1980; Rieger, 1983; Bliss, 1997; Korotaev, 1986), investigations in element translocation processes are still scarce. Results are predominantly of descriptive nature lacking pedogenetic information. To provide a better understanding of element translocation processes as a key to arctic soil genesis, a typical catena of polygonic soils along the island of Samoylov in the Lena Delta (Siberia) was investigated. The objective of this investigation was to identify and expound on the principal of element redistribution processes. It was hypothesized that within polygons (i) recent element redistribution via liquid phase caused by mobilization, transport, and immobilization processes was taking place and that (ii) these processes led to depletion and accumulation zones in the solid phase of polygonic soils. The controlling factors of these processes (iii) are hydraulic and redox gradients between microhighs and microlows.

\section{MATERIALS AND METHODS}

\section{Environmental Setting of the Study Sites}

Samoylov island ( $72^{\circ} 22^{\prime} \mathrm{N}$ Latitude, $126^{\circ} 28^{\prime} \mathrm{E}$ Long.) in the Lena River Delta (approximately $32000 \mathrm{~km}^{2}$, Are and

\footnotetext{
Abbreviations: subscript [d], dithionite citrate bicarbonate extractable; $\mathrm{D}_{\mathrm{b}}$, bulk density; Dpd, $\alpha$ - $\alpha$-dipyridil; $\mathrm{E}_{\mathrm{H}}$, oxidation-reduction (redox) potential; $\mathrm{Fe}_{\mathrm{t}}$, total iron; $\mathrm{K}_{\text {cal }}$, calcium lactate acetate extractable K; MC, matrix color; $\mathrm{Mn}_{\mathrm{t}}$, total manganese; $\mathrm{N}_{\mathrm{t}}$, total nitrogen; subscript [o], ammonium oxalate extractable; subscript [p], Na-pyrophosphate extractable; $\mathrm{P}_{\text {cal }}$, calcium lactate acetate extractable phosphorus (= plant available); PG1, Polygon 1; PG2, Polygon 2; $\mathrm{P}_{\mathrm{t}}$, phosphorus; SOC, soil organic carbon.
} 


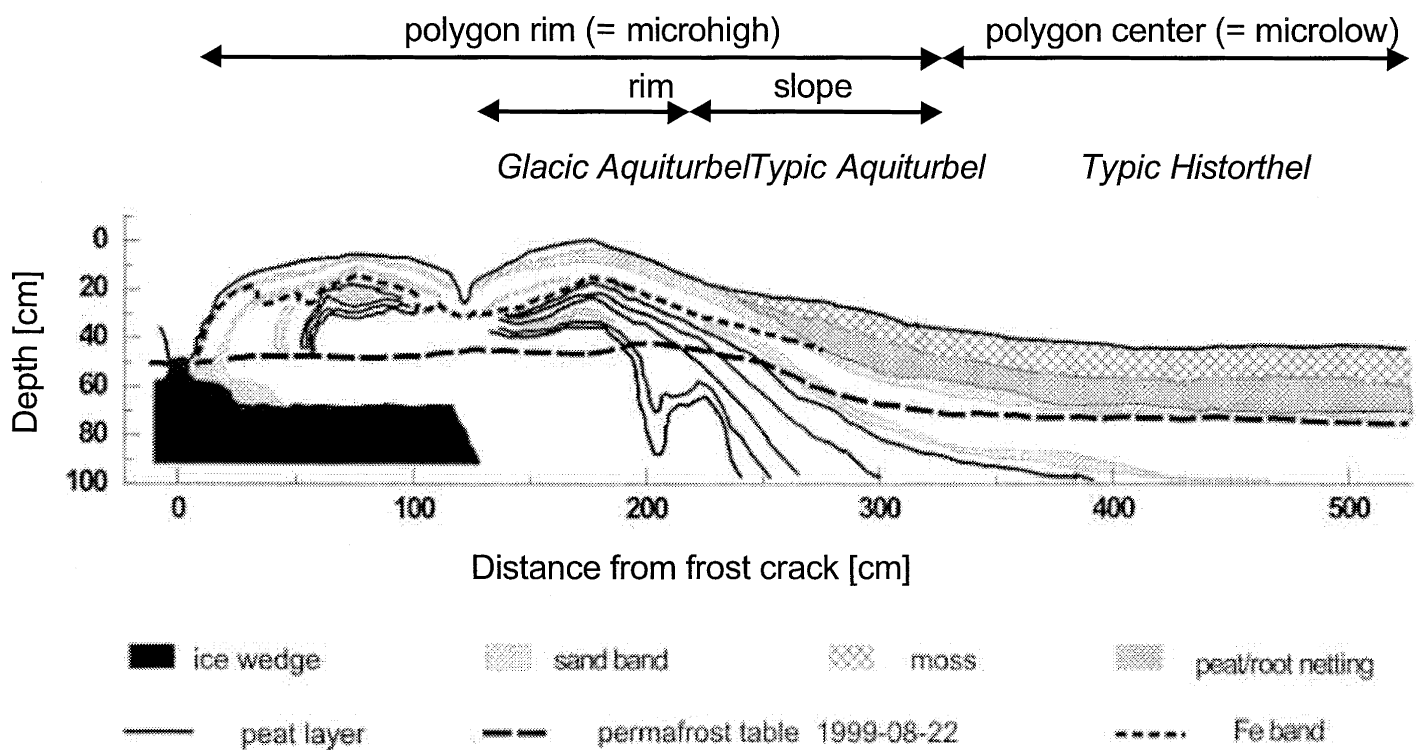

Fig. 1. Cross-section of a typical low-center polygon (Lena Delta, Northern Siberia).

Reimnitz, 2000) covers an area of approximately 1200 ha (Fig. 2) and portrays the active and youngest (approximately 8000-9000 yr) part of the delta (Schwamborn et al., 2002). Maximum altitude above mean sea level is $12 \mathrm{~m}$, representing the oldest part of the island. Shore sites with elevations of about $4 \mathrm{~m}$ above mean sea level are the lowest areas. Geomorphology of the island can be structured as follows (Akhmadeeva et al., 1999): the western part is characterized by recent depositional processes (sandy fluvial and aeolian sediments) and the eastern part is dominated by erosion processes that have formed an abrasion coast. Due to changes in river levels, four terraces were formed. Investigations were performed on the Middle-Holocene terrace, which was dominated by active ice wedge growth with low and high centered polygons and thermokarst lakes.
Two major topographic units $($ microhigh $=$ rim, microlow $=$ center) of two low-centered polygons (Polygon 1 = PG1, Polygon 2 = PG2) were selected. In addition, the middle transect position polygon slope (= microhigh) of one of the selected polygons was analyzed (PG1, Fig. 1). Depending on its position, a variety of wet arctic tundra vegetation grows on Samoylov from mossy tundra to wet fen and flooded sedges in the center of the polygons (Kutzbach, 2000).

Well-defined climatic distinctions between seasons are characteristic for the Lena Delta, which belongs to the continental area of the Arctic. Winter lasts 9 mo (end of September-end of May, $T_{\min }=-30^{\circ} \mathrm{C}$ January), is characterized by insufficient light (polar night) and severe snowstorms $\left(140 \mathrm{~km} \mathrm{~h}^{-1}\right.$, Wein, 1999). During the arctic summer of almost $12 \mathrm{wk}$, temperatures are above freezing point $\left(T_{\max }=7^{\circ} \mathrm{C}\right.$ July). Mean annual air

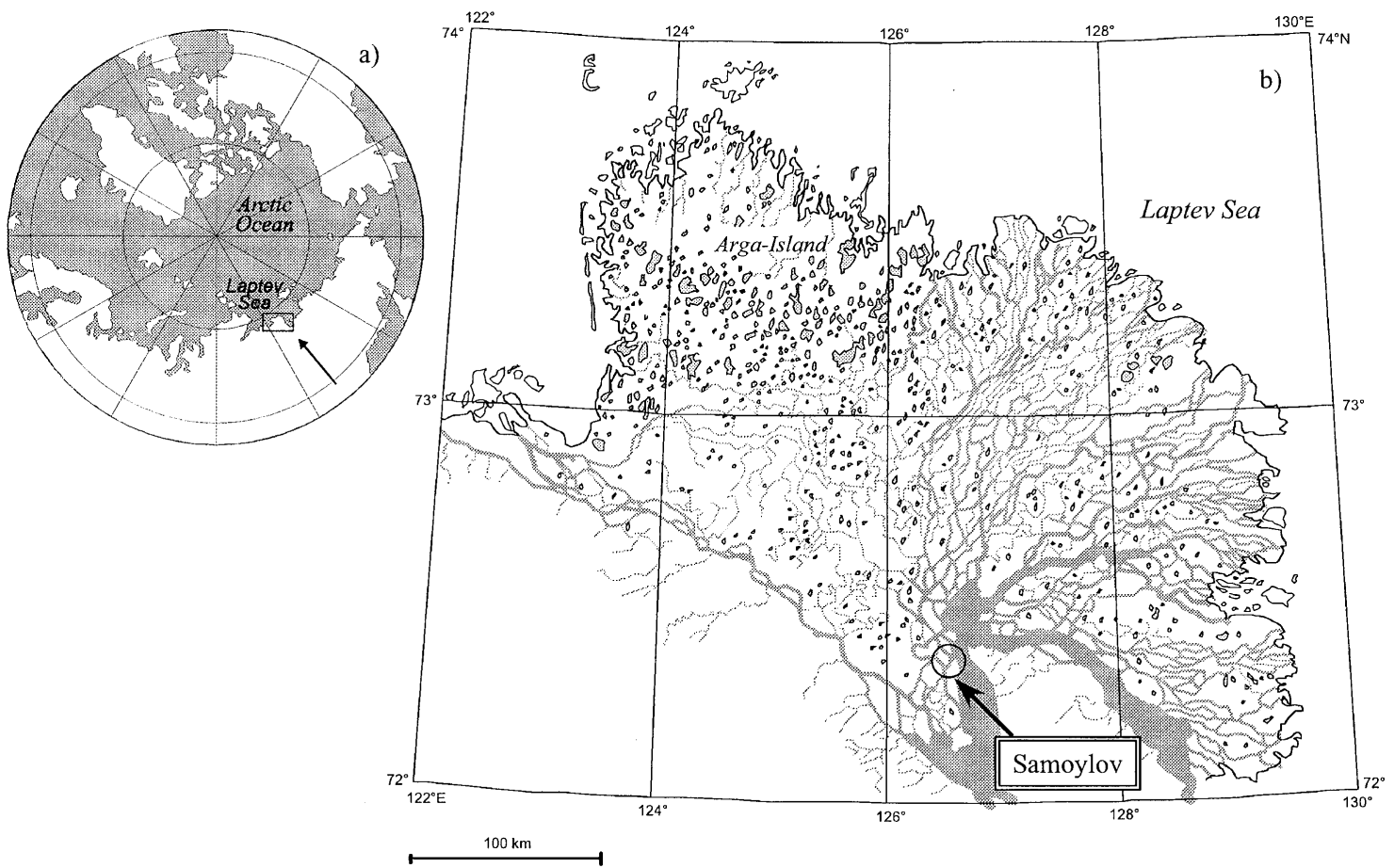

Fig. 2. The investigation site on the island Samoylov. (a) Map showing the location of the Lena Delta, and (b) location of the study area on the island Samoylov. 
temperature is $-12^{\circ} \mathrm{C}$, and mean annual precipitation amounts to $190 \mathrm{~mm}$. Approximately $25 \%$ of the annual precipitation is snow ( $<10 \mathrm{~mm}$ precipitation per month). Relative humidity is usually high (approximately $90 \%$ ), and the annual evapotranspiration averages at $100 \mathrm{~mm}$.

The investigations were performed during the summer of 1999 and 2000 within the framework of the joint cooperative Russian-German research project "Laptev Sea System 2000" (Pfeiffer et al., 2000; Wagner et al., 2001a). More details of the study sites have been described by Rachold and Grigoriev $(1999,2000,2001)$.

\section{Field Methods}

Every second day, thaw depth of the soil (active layer) and water levels were determined. Thaw depth was measured by pushing a steel rod into the soil until permafrost was encountered. Water table depths were measured in a series of slotted wells (polyvinylchloride, 6-cm i.d.). Redox potential $\left(\mathrm{E}_{\mathrm{H}}\right)$ was measured using Pt electrodes $(90 \% \mathrm{Pt}, 10 \% \mathrm{Ir}$, diameter of wires $=0.5 \mathrm{~mm}$, wire length $=10 \mathrm{~mm}$ ) as described by Fiedler (1997). Transects (from rim to center of polygon) along the two investigated polygons were equipped with a set of $30 \mathrm{Pt}$ electrodes installed at a depth of $5 \mathrm{~cm}$ and directly above the permafrost. An $\mathrm{Ag} / \mathrm{AgCl}$ electrode was used as a reference cell (Farrell et al., 1991). A data-logger (Delta-T-Devices LTD, Burwell, Cambridge, UK) was used for automatic readings at hourly intervals. Measurements were performed during summer (Period $1=29$ June -2 Sept. 1999, Period $2=1$ Aug. -21 Aug. 2000), the time with the highest biological activity. Redox data were corrected for the potential of the standard hydrogen electrode by adding $215 \mathrm{mV}\left(10^{\circ} \mathrm{C}\right)$ to experimental readings. In addition, anaerobic conditions (presence of $\mathrm{Fe}^{2+}$ ) were verified in field using the $\alpha$ - $\alpha$-dipyridyl (Dpd) test (Bartlett and James, 1995) during the soil description. Soil solution at different depths (polygon rim 14, 27, $39 \mathrm{~cm}$; polygon center $9,15 \mathrm{~cm}$ below surface) was collected three times during each measurement period by suction lysimeters. Manganese and Fe concentrations were determined by atomic absorption spectroscopy (AAS, Varian SpectrAA-200, Mulgrave Victoria, Australia).

\section{Soil Characterization}

Soil classification was determined according to U.S. Soil Taxonomy (Soil Survey Staff, 1999) and the World Reference Base of Soil Resources (ISSS-ISRIC-FAO, 1998). Microhighs were dominated by Typic Aquiturbels (Gleyi-Turbic Cryosols), whereas the prevalent soil type of the microlows was Typic Historthel (Gleyi-Histic Cryosol). Bulk density was measured using undisturbed soil cores $\left(100 \mathrm{~cm}^{3}\right.$, Schlichting et al., 1995, Method 5.3.1.1). Standard soil analyses were performed on the fine-earth fraction $(<2 \mathrm{~mm})$ : particle-size distribution (Schlichting et al., 1995, Method 5.4.1.3), $\mathrm{pH}\left(\mathrm{CaCl}_{2}\right)$ (Schlichting et al., 1995, Method 5.4.5.1.2), and total carbon $\left(\mathrm{C}_{\mathrm{t}}\right.$, dry combustion, Leco CN-2000, Leco Instruments $\mathrm{GmbH}$, Krefeld, Germany). In all soils investigated, SOC was equivalent to $\mathrm{C}_{\mathrm{t}}$. Plant available potassium $\left(\mathrm{K}_{\mathrm{cal}}\right)$, and phosphorus $\left(\mathrm{P}_{\text {cal }}\right)$ were determined by extraction with $0.1 \mathrm{M}$ calcium lactate plus $0.1 M$ calcium acetate plus $0.3 M$ acetic acid (CAL, Schüller, 1969). Potassium in the extract was analyzed using flame emission spectroscopy (Elex 6361, Eppendorf, Hamburg, Germany). Determination of $\mathrm{P}$ was done by the molybdenum blue method of John (1970). Phosphorus was measured as molybdate-phosphate complex at $\varepsilon=880 \mathrm{~nm}$ using a spectrophotometer (Zeiss PL2DL, Germany). Pedogenetic oxides were extracted by dithionite citrate bicarbonate $\left(\mathrm{Mn}_{\mathrm{d}}, \mathrm{Fe}_{\mathrm{d}}\right.$,
Schlichting et al., 1995, Method 5.5.5.3) (Mehra and Jackson, 1960) and ammonium oxalate $\left(\mathrm{Mn}_{0}, \mathrm{Fe}_{0}\right.$, Schlichting et al., 1995, Method 5.5.5.2) (Schwertmann, 1964), and analyzed by atomic absorption spectrometry. The portion of organically bound $\mathrm{Mn}_{\mathrm{p}}$ and $\mathrm{Fe}_{\mathrm{p}}$ was extracted by Na-phyrophosphate at pH 10 (von Zezschwitz et al., 1973). Total element analysis $\left(\mathrm{Mn}_{\mathrm{t}}, \mathrm{Fe}_{\mathrm{t}}, \mathrm{P}_{\mathrm{t}}\right)$ was performed with X-ray fluorescence (Siemens SRS-200, Bruker AXS, Karlsruhe, Germany).

\section{Calculation}

Element masses per total soil volume of the active layer were calculated as follows (Sommer et al., 1997):

$$
M_{\mathrm{x}}=\sum_{i=1}^{n}\left(x_{i} \mathrm{D}_{\mathrm{b}_{i}} y_{i} \frac{100-c f_{i}}{10000}\right)
$$

$M_{\mathrm{x}}$ is the mass of $\mathrm{P}, \mathrm{Fe}$, or $\mathrm{Mn}$ in the pedon fine-earth ( $\mathrm{kg}$ $\mathrm{m}^{-2}$ profile depth $\left.{ }^{-1}\right) ; X_{i}$ is $\mathrm{P}, \mathrm{Fe}$, or $\mathrm{Mn}$ content $(<2 \mathrm{~mm})$ in horizon $i$ ( $\mathrm{g} \mathrm{kg}^{-1}$ fine-earth); $N$ is the number of horizons to profile depth; $D_{\mathrm{b}}$ is bulk density $\left(\mathrm{g} \mathrm{m}^{-3}\right) ; Y_{i}$ is the thickness of the horizon $i(\mathrm{~cm}) ; C f_{i}$ is the coarse fraction $(>2 \mathrm{~mm})$ of the horizon $i$ (vol. \%).

\section{RESULTS AND DISCUSSION Water Level and Permafrost Table}

The two investigated polygons were characterized by very flat relief ( $\Delta$ height, PG1 $=37, \mathrm{PG} 2=22 \mathrm{~cm}$ over a distance of approximately $600 \mathrm{~cm}$ ) (Fig. 4). According to Boike (1997) and Boike et al. (1998), seasonal hydrology can be described as follows: at the beginning of snowmelt, water flows laterally from microhighs to microlows. This leads to a supersaturation zone in the polygon center (water table ranged from +10 to $-5 \mathrm{~cm}$ below surface, Fig. 3), which lasts until freezing in autumn. On the contrary, the water table of microhighs rapidly drops to the permafrost table from spring to summer ( 0 to $-40 \mathrm{~cm}$ below surface).

The ground thaws rapidly until mid-June (after 18 June, Julian day 169) after which thaw rates are somewhat slower (Fig. 3). Thickness of the active layer varies from year to year in response to climatic conditions. Within the polygons, permafrost is deepest under the rim at the end of measurement periods (August 1999 vs. 2000,44 vs. $38 \mathrm{~cm}$ ) and most shallow in the polygon center ( 35 vs. $28 \mathrm{~cm}$ below surface). Maximum thaw depth was reached at the beginning of September. Summer in 1999 was warm and dry (August, average air temperature $=7.8^{\circ} \mathrm{C}, T_{\min }=0.6^{\circ} \mathrm{C}, T_{\max }=23^{\circ} \mathrm{C}$, precipitation $=11.1 \mathrm{~mm}$ ), while the same period in 2000 was characterized by lower temperature (average $=$ $5.5^{\circ} \mathrm{C}, T_{\min }=2.5^{\circ} \mathrm{C}, T_{\max }=10.5^{\circ} \mathrm{C}$ ) and higher precipitation $(20 \mathrm{~mm})$. For both measurement periods, high evapotranspiration favored by continuous and strong winds was presumed.

\section{Redox Regime}

Pronounced differences in soil moisture characteristics depending on topography were coupled with regular patterns of redox conditions (Fig. 4). Permanently submerged microlows showed strongly reducing conditions without an intrapedon redox gradient (topsoil approxi- 

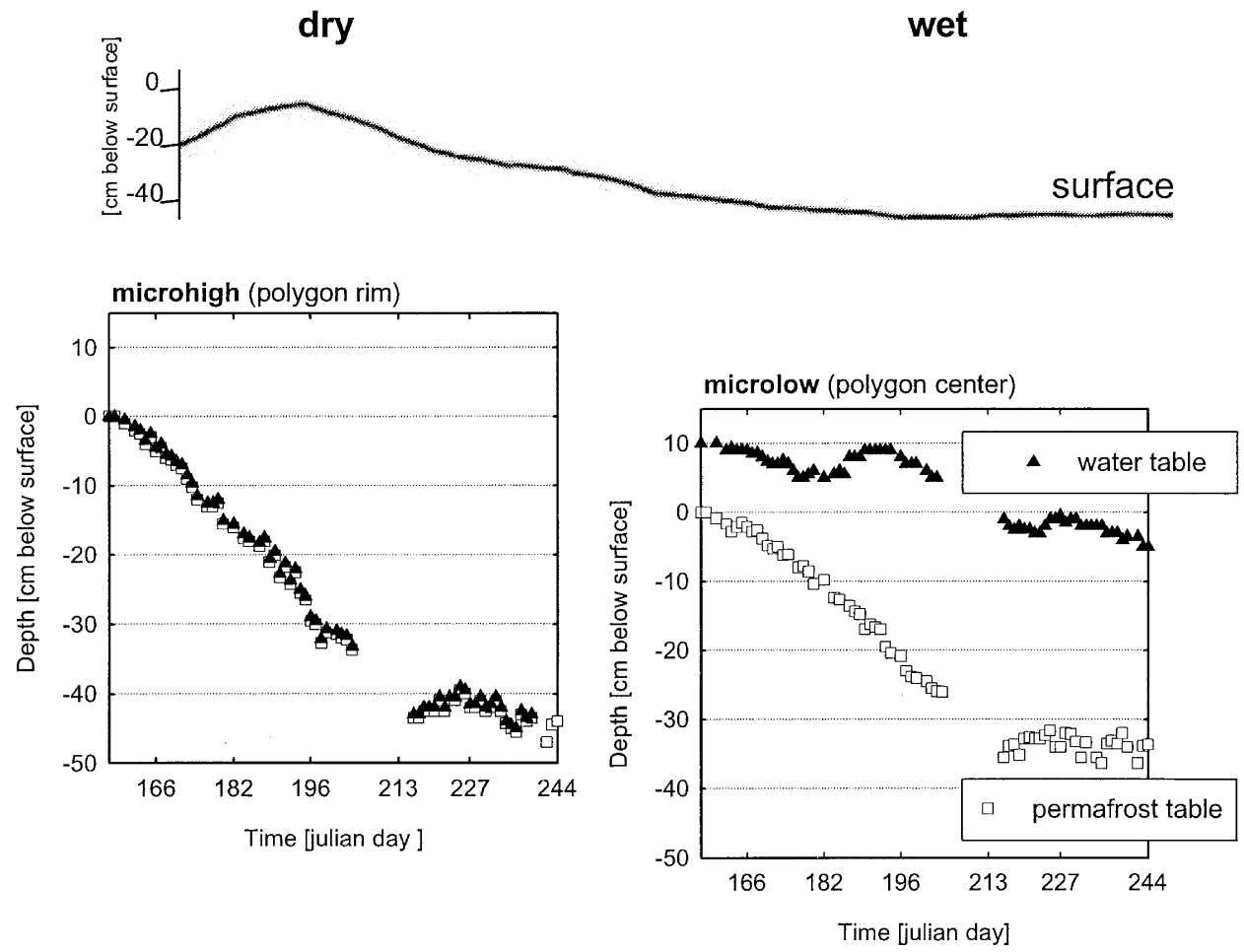

Fig. 3. Permafrost and water table of the low-center Polygon 1 (measurement period $=6$ June to 1 Sept. 1999).

mately $-50 \mathrm{mV}$, just above the permafrost table approximately $-90 \mathrm{mV}$ ). Microhighs were distinguished into an oxidative layer at a depth of $5 \mathrm{~cm}$ below surface (approximately 300-400 $\mathrm{mV}$ ) and a reductive layer near the permafrost (approximately 180-0 $\mathrm{mV}$ ) (= intrapedon upward gradient of $\left.\mathrm{E}_{\mathrm{H}}\right)$. Abrupt $\mathrm{E}_{\mathrm{H}}$ changes could be observed from microlows to microhighs (= interpedon
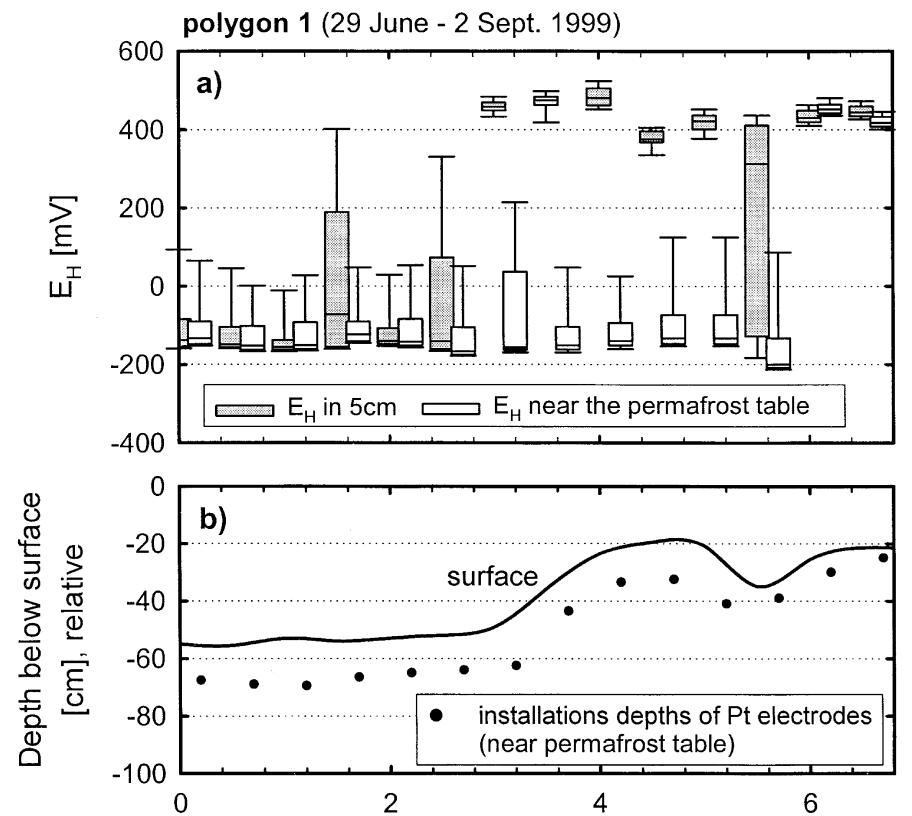

gradient of $\left.\mathrm{E}_{\mathrm{H}}\right)$. These changes were only registered in the upper soil zone $(5 \mathrm{~cm})$. Measurements near the permafrost table indicated uniform reducing conditions in all microtopographical units. The slope had a transient position and was dominated by higher $\mathrm{E}_{\mathrm{H}}$ fluctuations than other positions (Fig. 4c).

The redox conditions must be regarded as a result polygon 2 (1 Aug. - 21 Aug. 2000)

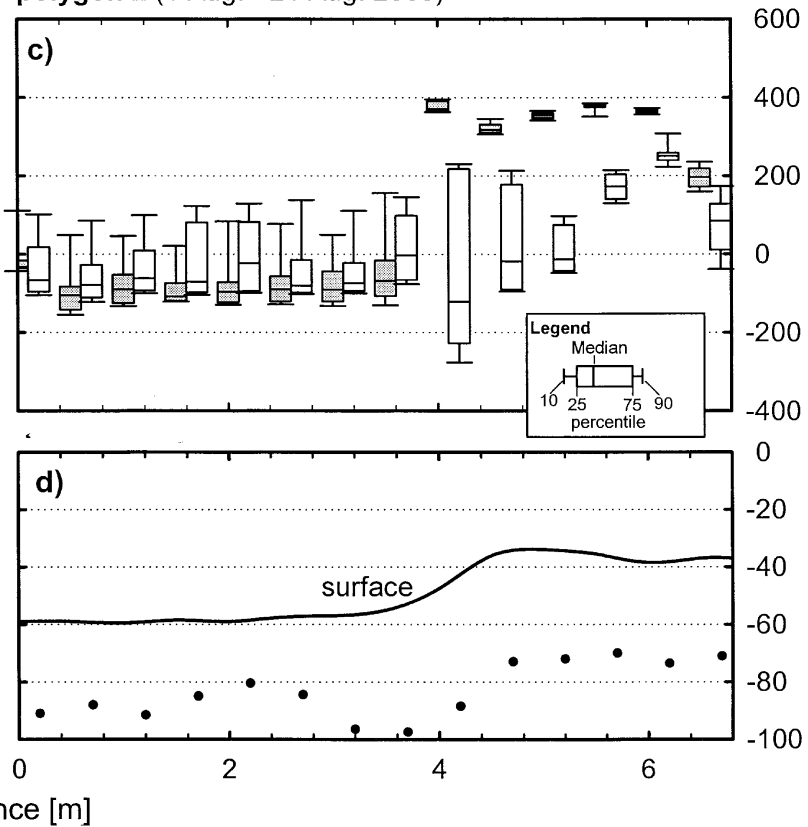

Fig. 4. Relationship between topography and redox regime. The oxidation-reduction values distribution in form of box plots (see legend) (a) Polygon 1 and (c) Polygon 2. Cross section through studied low-center polygons with morphological units and installation depths (points filled in black) of the lower electrodes (directly above the permafrost table), (b) Polygon 1 (day of installation 28 June 1999), (d) Polygon 2 (day of installation 30 July 2000). 
of microbial processes, which can be demonstrated by methane dynamics. Under anoxic conditions, as in the polygon center and permafrost boundary of the polygon rim, $\mathrm{C}$ decomposition in the course of microbial methane formation by strictly anaerobic organisms (methanogenic archaea) dominates. Within overlying oxic horizons so-called methane-oxidizing bacteria use the energy of transforming $\mathrm{CH}_{4}$ to $\mathrm{CO}_{2}$. The relationship between redox potential and involved microbial processes gives reason for methane fluxes in the Lena Delta being largely dependent on topographic position (Kutzbach 2000; Wagner et al., 2003). The latter authors noticed higher methane emission from the polygon center (25-75 mg CH $\mathrm{CH}_{4} \mathrm{~d}^{-1} \mathrm{~m}^{-2}$ ) than from the rim (up to $6 \mathrm{mg}$ $\mathrm{CH}_{4} \mathrm{~d}^{-1} \mathrm{~m}^{-2}$ ). While descriptive reports of $\mathrm{E}_{\mathrm{H}}$ from permafrost soil studies are numerous (Bleich and Stahr, 1978), $E_{H}$ measurements within cryogenic soils are rare. Limited information is available on $\mathrm{E}_{\mathrm{H}}$ measurements over a longer period than a couple of hours (Clark and Ping, 1997). However, single measurements of other studies have shown similar trends. Beyer et al. (1995) registered $\mathrm{E}_{\mathrm{H}}$ values (after $12 \mathrm{~h}$ of installation) between $600 \mathrm{mV}$ (topsoil) and approximatley $200 \mathrm{mV}(18 \mathrm{~cm}$ below surface) in two Histosols within Antarctica. Mueller (1997) indicated that, at the slope of a comparably wet polygon in the Lena Delta, $\mathrm{E}_{\mathrm{H}}$ values were approximately $130 \mathrm{mV}$ in the zone near the permafrost table (immediately after installation). The oxidationreduction potential data presented here tended to be lower than those in both of the latter studies, which can easily be explained by the different measurement durations. It is well known that single $\mathrm{E}_{\mathrm{H}}$ measurements can lead to false conclusions (Böttcher and Strebel, 1988). In this study, high daily fluctuations $\left(\Delta \mathrm{E}_{\mathrm{H}}=200\right.$ $\mathrm{mV}$ ) as well as the synchronous decrease of $E_{H}$ (polygon center near the permafrost table $200 \rightarrow-100 \mathrm{mV}$ ) were observed in the first $5 \mathrm{~d}$ after installation followed by relatively constant values.

\section{Soil Properties and Element Distribution}

All soils exhibited typical properties of alluvial soils (in this case, fluvial $\gg$ aeolian sedimentation): (i) high amounts of sand and silt, (ii) noticeable changes in texture and (iii) irregular $\mathrm{C}$ contents from one horizon to another (Table 1). The two polygons showed a high spatial variability of $\mathrm{C}$ content, which has been documented by numerous studies in polar regions (Brown, 1967; Beyer et al., 2000; Bockheim et al., 2003). Carbon/N ratios of rim horizons ranged from 14 to 16 (PG2) and from 21 to 24 (PG1). Values of center horizons ranged from 24 to 25 (PG2) and from 35 to 42 (PG1). Higher ratios of the anoxic center profiles coincided with a higher $\mathrm{C}$ accumulation $\left(\mathrm{PG} 1=17 \mathrm{~kg} \mathrm{SOC} \mathrm{m}^{-2}\right.$ ) compared with oxic rim profiles $\left(11 \mathrm{~kg} \mathrm{SOC} \mathrm{m}^{-2}\right)$.

Investigated polygons were nutrient-limited (input $\ll$ biorecycling) and adhere to findings of Alexander and Schell (1973) and Haag (1974) in Alaska and Canada. The contents of plant available P only amounted to half of the content in soils investigated by Mueller (1997) in the same area. The storage of $\mathrm{P}_{\text {cal }}$ ranged between $5 \mathrm{~g} \mathrm{~m}^{-2}$ (microhighs) and $2.4 \mathrm{~g} \mathrm{~m}^{-2}$ (microlows) in this study. Potatssium contents were comparable in both studies. In general, $\mathrm{K}$ stock was higher on microhighs $\left(22 \mathrm{~g} \mathrm{~m}^{-2}\right)$ compared with the microlows $\left(15 \mathrm{~g} \mathrm{~m}^{-2}\right)$. Low temperature and insufficiency of $\mathrm{N}\left(\mathrm{N}_{\mathrm{t}}\right.$ ranged from 0.2 to $6 \mathrm{~g}$ $\mathrm{kg}^{-1}$, Table 1) and $\mathrm{P}$ ( $\mathrm{P}$ ranged from 2 to $30 \mathrm{mg} \mathrm{kg}^{-1}$ ) led to restricted production of phytomass. According to Kutzbach (2000), phytomass amounted to $1100 \pm 40 \mathrm{~g} \mathrm{~m}^{-2}$ (dry mass) in the center and $420 \pm 50 \mathrm{~g} \mathrm{~m}^{-2}$ on the polygon rim. Development of dense root systems is characteristic for tundra vegetation and indicates adaptation to a restricted nutrient supply and saturated/reducing conditions (McCown, 1978).

Total $\mathrm{Mn}$ and $\mathrm{Fe}$ within the active layer ranged from 208 to $920 \mathrm{mg} \mathrm{Mn} \mathrm{kg}^{-1}$ and 17 to $30 \mathrm{~g} \mathrm{Fe} \mathrm{kg}^{-1}$ soil in the rim of PG1 vs. 320 to $430 \mathrm{mg} \mathrm{Mn} \mathrm{kg}{ }^{-1}$ and 17 to $27 \mathrm{~g} \mathrm{Fe} \mathrm{kg}^{-1}$ of PG2; values in the center of PG1 ranged from 225 to $400 \mathrm{mg} \mathrm{Mn} \mathrm{kg} \mathrm{m}^{-1}$ and 14 to $19 \mathrm{~g} \mathrm{Fe} \mathrm{kg}^{-1}$ compared with 215 to $321 \mathrm{mg} \mathrm{Mn} \mathrm{kg}{ }^{-1}$ and 16 to $18 \mathrm{~g}$ Fe kg-1 in PG2 (Table 1). A parallel trend of $\mathrm{Mn}_{\mathrm{t}}$ as well as $\mathrm{Fe}_{\mathrm{t}}$ and dithionite-extractable $\mathrm{Mn}$ and $\mathrm{Fe}\left(\mathrm{Mn}_{\mathrm{d}}\right.$, $\mathrm{Fe}_{\mathrm{d}}$ ) was recognized. Manganese and $\mathrm{Fe}$ accumulated above the water table, in unsaturated well-drained horizons, which can be inferred by higher values of $\mathrm{Fe}_{\mathrm{d}}$ and $\mathrm{Mn}_{\mathrm{d}}$ (10.7 $\mathrm{g} \mathrm{Fe} \mathrm{kg}^{-1}, 443 \mathrm{mg} \mathrm{Mn} \mathrm{kg}{ }^{-1}$ in Bjjg1, PG1) (Table 1). In contrast, $\mathrm{Mn}_{\mathrm{t}}, \mathrm{Fe}_{\mathrm{t}}$, and $\mathrm{Mn}_{\mathrm{d}}, \mathrm{Fe}_{\mathrm{d}}$ was lowest in the very poorly drained active layer at the polygon center (3.7 $\mathrm{g} \mathrm{Fe}_{\mathrm{d}} \mathrm{kg}^{-1},<50 \mathrm{mg} \mathrm{Mn} \mathrm{kg}^{-1}$ in $\mathrm{Bg}$, PG1). Along the microrelief, a stepwise decline of the portion of organic-bound $\mathrm{Fe}$ and $\mathrm{Mn}$ within $\mathrm{A}$ and $\mathrm{O}$ horizons from the center (PG1, $\mathrm{Fe}_{\mathrm{p}} / \mathrm{Mn}_{\mathrm{p}} \sim 0.4 \mathrm{~g} \mathrm{~kg}^{-1} / 63 \mathrm{mg} \mathrm{kg}{ }^{-1}$ ) to the slope $\left(\mathrm{Fe}_{\mathrm{p}} / \mathrm{Mn}_{\mathrm{p}} \sim 0.7 \mathrm{~g} \mathrm{~kg}^{-1} / 150 \mathrm{mg} \mathrm{kg}{ }^{-1}\right)$ to the rim $\left(\mathrm{Fe}_{\mathrm{p}} / \mathrm{Mn}_{\mathrm{p}} \sim 2 \mathrm{~g} \mathrm{~kg}^{-1} / 200 \mathrm{mg} \mathrm{kg}{ }^{-1}\right)$ was observed. Additionally, with exception of the Typic Aquiturbel at the rim of PG2, a weak element enrichment in the permafrost fringe occurred (PG1, polygon center, $\mathrm{Bg}=$ 15.2 vs. $\left.\mathrm{Bf}=19.7 \mathrm{~g} \mathrm{Fe}_{\mathrm{t}} \mathrm{kg}^{-1}\right)$.

All soils contained redoximorphic features corresponding to element distribution reflected by distinct redox states. Soils on the rim were hydromorphic with brownish, Mn- and Fe-enriched horizons above bluegreyish Fe-impoverished subsoil horizons close to the permafrost table. The Dpd test indicated oxic conditions over great depths (PG1/PG2, 32/33 cm below surface). In polygon center soils, the typical blue-greyish color (2.5Y 4/4) indicated reducing conditions just below the surface (PG1/PG2, 26/22cm below surface) (Table 1).

\section{Mechanisms of Element (Matter) Redistribution}

\section{Downward-Translocation}

Element redistribution via solid soil phase was observed only within microhighs. These geomorphic units were characterized by twisted and mixed soil horizons (Turbel, Fig. 1). Cryoturbation plays an important role in mixing surface organic matter into the subsoil (Bockheim and Tarnocai, 1998; Bockheim et al., 1999, 2003). Based on radiocarbon dating (Mueller, 1997), the maximum age of buried organic matter at a 1-m depth was dated between 1530 and $1570 \mathrm{yr}$. It can be assumed that 
Table 1. Selected soil properties of the study sites. $\dagger$

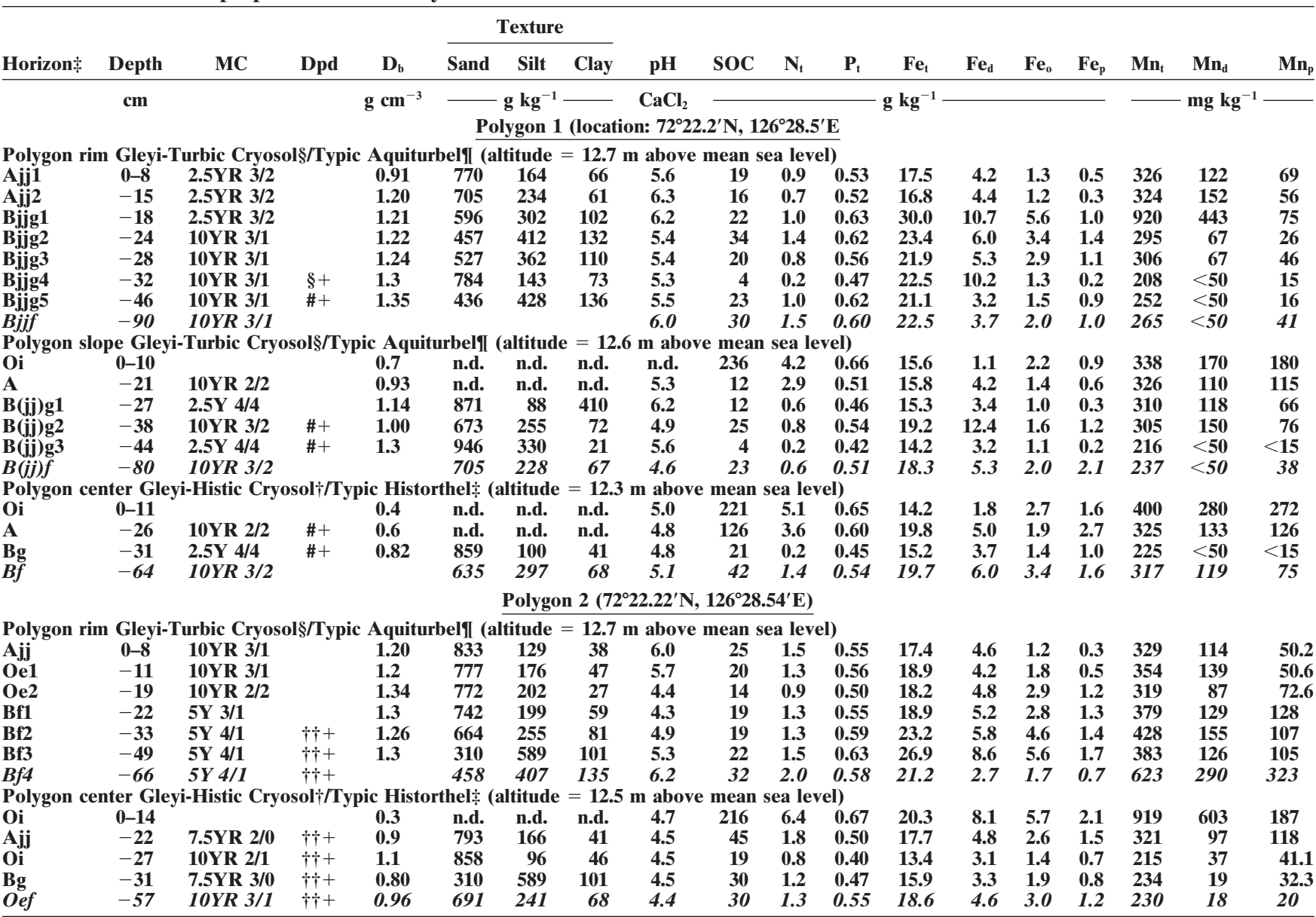

$\dagger \mathrm{MC}=$ matrix color; $\mathbf{D p d}=\alpha$ - $\alpha$-Dipyridil-test $(+)=$ positive, day of description; $\mathbf{D}_{\mathrm{b}}=$ bulk density; $\mathbf{F e}_{\mathrm{o}}=$ ammonium oxalate extractable iron; $\mathbf{F e}_{\mathrm{p}}$,

$\mathrm{Mn}_{\mathrm{p}}=$ pyrophosphate extractable iron and manganese; n.d. $=$ not determined; italic letters $=$ horizons in the range of permafrost.

+ Horizon nomenclature according to Soil Survey Staff (1999).

$\S$ Soil classification according to ISSA-ISRIC-FAO (1998).

II Soil classification according to Soil Survey Staff (1999).

\# 22 Aug. 1999.

$\dagger+19$ Aug. 2000.

buried and twisted organic layers (Fig. 1) which now are parts of the perennial frozen layer were once close to the surface. Cryoturbation of organic and mineral material into the subsoils results in a relative enrichment of elements and organic matter (Fig. 5a). The sedimentation layers within the polygon center were not deformed, which was indicated by their horizontal orientation (Orthel).

A weak element enrichment at the permafrost fringe was recorded in all geomorphic units. This suggested a downward migration of ions (solutional phase) via gravitation to the contact with the frozen ground (Fig. 5b). Lundin and Johnsson (1994) also found a similar movement of mass flow by thermal gradients during the snowmelt. Boike (1997) and Boike et al. (1998) found up to $9 \%$ of liquid water in permafrost $\left(-12^{\circ} \mathrm{C}\right)$ on the Taymyr Peninsula (Siberia). Overduin and Young (1997) explained the element enrichment by cumulative effect of solute exclusion over a repeated freeze-thaw cycles, and to the accumulation of solutes through convective transport of soil water to the freezing front due to ice lens formation.

\section{Upward-Translocation}

The lateral upward-translocation of water-soluble elements in continental climates was described by Arndt and Richardson (1989), and was generalized by Sommer and Schlichting (1997). This translocation process affecting the entire catena was restricted to a very flat relief. The driving factor was the upward gradient of the water potential between microlows and microhighs. This gradient occurred during summer and was principally caused by higher evapotranspiration from soils of the microhighs (higher surface/volume ratio) compared with soils of the microlows. In addition, vegetation on microhighs acts as a large water pump resulting in a lowering of the water table (Richardson et al., 2001). Furthermore, it can be assumed the gradient was additionally supported by higher proportions of fine macro- and mesopores at the rim (PG1, in a depth of $28 \mathrm{~cm}=37 \%$ ) compared with the polygon center (in a depth of $31 \mathrm{~cm}=$ $20 \%$ ) (Kutzbach, 2000). When soils are dry the matrix potential increases and the soil water moves via capillary transporting solutes (Richardson et al., 2001). The latter 


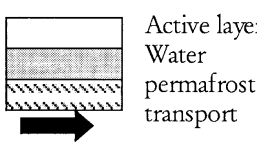

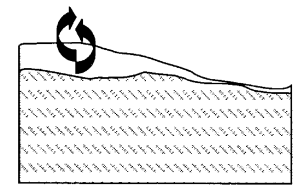

5a)

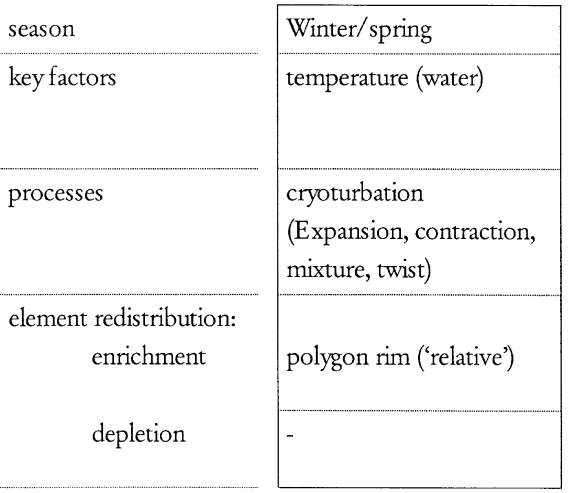

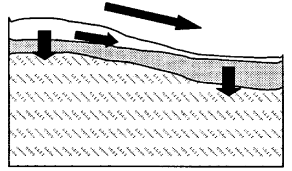

$5 b)$

\begin{tabular}{|l|}
\hline Spring/snowmelt \\
gravitation/thermal \\
gradients \\
\hline $\begin{array}{l}\text { Leaching, exclusion, } \\
\text { convection }\end{array}$ \\
permafrost fringe \\
\hline active layer \\
\hline
\end{tabular}

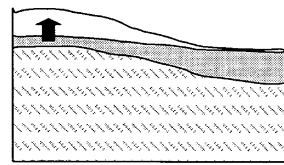

5c)

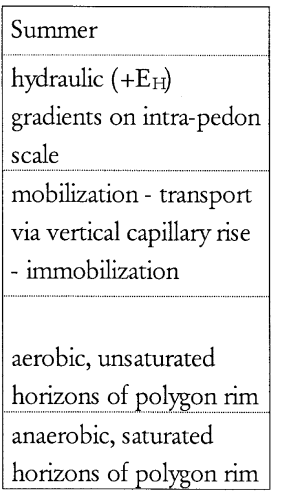

Upward translocation

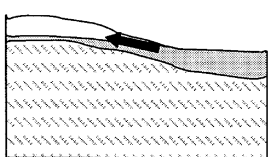

5d)

\begin{tabular}{|l|}
\hline (dry) Summer \\
\hline $\begin{array}{l}\text { hydraulic }\left(+\mathrm{E}_{\mathrm{H}}\right) \\
\text { gradients on inter-pedon } \\
\text { scale }\end{array}$ \\
\hline $\begin{array}{l}\text { mobilization - transport } \\
\text { via lateral capillary rise - } \\
\text { immobilization, }\end{array}$ \\
\hline $\begin{array}{l}\text { dry/aerobic polygon } \\
\text { slope and rim }\end{array}$ \\
\hline $\begin{array}{l}\text { wet/anaerobic polygon } \\
\text { center }\end{array}$ \\
\hline
\end{tabular}

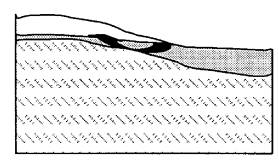

5e)

\begin{tabular}{|l|}
\hline Autumn / refreezing \\
\hline thermal gradients \\
transport via unfrozen \\
water films \\
dry polygon rim \\
\hline wet polygon center \\
\hline
\end{tabular}

Fig. 5. Model of different kinds of element redistribution within low-center polygons.

process can be reconstructed using the contents of K. Potassium can easily be leached in soils with poor clay contents, because its bondage to organic matter is negligible (Schachtschabel et al., 1998). Consequently, water soluble $\mathrm{K}$ can migrate along water potentials resulting in a higher $\mathrm{K}$ storage in microhighs (PG1, polygon rim, $\left.22 \mathrm{~g} \mathrm{~m}^{-2}\right)$ than in the microlows $\left(15 \mathrm{~g} \mathrm{~m}^{-2}\right)$. The results are supported by many other studies, which focused on the upward-translocation of salts (Kellog, 1934; Douglas and Tedrow, 1960; Whittig and Janitzky, 1963; Wiegand et al., 1966; MacLean and Pawluck, 1975; Hallsworth et al., 1982) and gypsum (Steinwand and Richardson, 1989) within very flat geomorphic units.

Parallel to K, an upward-translocation of redox-sensitive elements $(\mathrm{Mn}, \mathrm{Fe})$ was also recorded. Migration of these elements is coupled to changes in valence caused by electron transfer. Thus, redox (and hydraulic) gradi-

Table 2. Absolute mass based on active layer $\left(\mathrm{g} \mathrm{m}^{2}\right)$ of soils studied. $\dagger$

\begin{tabular}{|c|c|c|c|c|c|c|c|}
\hline $\mathbf{P}_{\mathrm{t}}$ & $\mathbf{F e}_{\mathrm{t}}$ & $\mathbf{F e}_{\mathrm{d}}$ & $\mathbf{F e}_{\mathbf{o}}$ & $\mathbf{F e}_{\mathrm{p}}$ & $\mathbf{M n}_{\mathrm{t}}$ & $\mathbf{M n} \mathbf{n}_{\mathrm{d}}$ & M \\
\hline \multicolumn{8}{|c|}{ PG1, polygon rim Gleyi-Turbic Cryosolł̦/Typic Aquiturbel§̧ } \\
\hline 320 & 11730 & 2896 & 1146 & 435 & 179 & 46 & \\
\hline \multicolumn{8}{|c|}{ PG1, polygon slope Gleyi-Turbic Cryosol $\$$ /Typic Aquiturbel§ } \\
\hline 212 & 6967 & 2355 & 630 & 296 & 128 & 47 & \\
\hline \multicolumn{8}{|c|}{ PG1, polygon center Gleyi-Histic Cryosolł̦/Typic Historthel§ } \\
\hline 101 & 3032 & 682 & 341 & 355 & 56 & 24 & \\
\hline \multicolumn{8}{|c|}{ PG2, polygon rim Gleyi-Turbic Cryosolł̣/Typic Aquiturbel§ } \\
\hline 360 & 13850 & 3905 & 2408 & 774 & 232 & 78 & \\
\hline \multirow{2}{*}{\multicolumn{8}{|c|}{ PG2, polygon center Gleyi-Histic Cryosol/Typic Historthel\$ }} \\
\hline 101 & & 960 & 564 & 258 & 81 & 35 & 2 \\
\hline
\end{tabular}

$\dagger \mathbf{P}_{\mathrm{t}}, \mathbf{F e}_{\mathrm{t}}, \mathbf{M n}_{\mathrm{t}}=$ total phosphorus, iron, manganese; $\mathbf{F e}_{\mathrm{d}}, \mathbf{M n}_{\mathrm{d}}=$ dithionite citrate bicarbonate extractable iron and manganese, $\mathbf{F e}_{\mathrm{o}}=$ ammonium oxalate extractable iron; $\mathbf{F e}_{\mathrm{p}}, \mathbf{M n}_{\mathrm{p}}=$ pyrophosphate extractable iron and manganese.

$¥$ Soil classification according to ISSA-ISRIC-FAO (1998).

$\S$ Soil classification according to Soil Survey Staff (1999). ents control the element redistribution within low-centered polygons. Continuous redox measurements demonstrated strong redox gradients, which lead to an upward element transport along these gradients. After element mobilization in the reducing center and, subsequent, upward transport along $\mathrm{E}_{\mathrm{H}}$ gradients via capillary rise, immobilization processes occurred in the oxic microhighs. The latter can be explained by an abrupt change in the redox environment (Fig. 4). Consequently, in both polygons, a higher absolute element mass was calculated in the well-drained microhighs (PG1 rim/ slope; $\mathrm{Fe}_{\mathrm{t}}=11.7 / 7 \mathrm{~kg} \mathrm{~m}^{-2}, \mathrm{Fe}_{\mathrm{d}}=2.9 / 2.3 \mathrm{~kg} \mathrm{~m}^{-2}, \mathrm{Fe}_{\mathrm{o}}=$ $\left.1.1 / 0.6 \mathrm{~kg} \mathrm{~m}^{-2}\right)$ compared with the microlows $\left(\mathrm{Fe}_{\mathrm{t}}=3\right.$ $\mathrm{kg} \mathrm{m}^{-2}, \mathrm{Fe}_{\mathrm{d}}=0.7 \mathrm{~kg} \mathrm{~m}^{-2}, \mathrm{Fe}_{\mathrm{o}}=0.3 \mathrm{~kg} \mathrm{~m}^{-2}$, Table 2). On the contrary, the liquid phase of the center profiles was characterized by higher Mn and Fe concentrations than that of the rim profiles (approximately $4 \mathrm{mg} \mathrm{Mn}$ $\mathrm{L}^{-1}$ soil solution, approximately $2.9 \mathrm{mg} \mathrm{Fe} \mathrm{L}^{-1}$, vs. approximately $1.2 \mathrm{mg} \mathrm{Mn} \mathrm{L}^{-1}$, and $0.2 \mathrm{mg} \mathrm{Fe} \mathrm{L}^{-1}$, Table 3). The $\mathrm{Fe}$ accumulation at the polygon rim was visible in as continuous Fe-band, which regularly followed the buckling surface (Fig. 1). This element accumulation due to upward migration from bottom of the drainage way to a slightly higher elevation along the adjacent slope was referred to in the literature as edge effect (Steinwand and Richardson, 1989; Sommer and Schlichting, 1997). Similar research (Everett and Parkinson, 1977; Everett and Brown, 1982) described an upward Fe translocation along a microcatena (Cryaquept-Cryofibrist) of Alaskan tundra soils. Researchers observed an Fe accumulation solely in microhighs and explained this phenomenon by Fe flux via groundwater combined with a redox 
Table 3. Characterization of soil solution (Polygon 1[PG1]).

\begin{tabular}{|c|c|c|c|c|c|c|c|c|c|c|c|c|c|}
\hline \multirow[b]{3}{*}{ Position } & \multirow[b]{3}{*}{ Depth } & \multicolumn{12}{|c|}{ Sampling date } \\
\hline & & \multicolumn{2}{|c|}{7 July 1999} & \multicolumn{2}{|c|}{14 July 1999} & \multicolumn{2}{|c|}{21 July 1999} & \multicolumn{2}{|c|}{7 Aug. 2000} & \multicolumn{2}{|c|}{14 Aug. 2000} & \multicolumn{2}{|c|}{21 Aug. 2000} \\
\hline & & $\mathbf{F e}$ & Mn & $\mathbf{F e}$ & Mn & $\mathbf{F e}$ & Mn & $\mathbf{F e}$ & Mn & $\mathbf{F e}$ & Mn & $\mathrm{Fe}$ & Mn \\
\hline & cm & & & & & & -1 & & & & & & \\
\hline $\operatorname{Rim}$ & 14 & n.d. $\dagger$ & n.d. & 0.12 & 0.20 & n.d. & n.d. & 0.08 & 0.06 & 0.07 & 0.05 & 0.08 & 0.07 \\
\hline Rim & 27 & 0.09 & 0.13 & 0.10 & 0.67 & 0.14 & 0.79 & 0.09 & 1.98 & 0.11 & 1.61 & 0.19 & 1.66 \\
\hline $\operatorname{Rim}$ & 36 & 0.20 & 0.63 & 0.27 & 1.51 & 0.38 & 1.92 & 0.42 & 2.74 & 0.41 & 3.07 & 0.54 & 2.81 \\
\hline Center & 9 & n.d. & n.d. & $\mathbf{0 . 3 3}$ & 4.28 & n.d. & n.d. & 1.71 & 1.35 & 10.43 & 8.24 & 0.36 & 9.74 \\
\hline Center & 15 & 4.27 & 4.89 & 0.41 & 2.24 & 0.71 & 2.16 & 0.57 & 2.65 & 0.49 & 2.59 & 0.43 & 2.65 \\
\hline
\end{tabular}

$\dagger$ not determined.

gradient (oxic conditions in microhighs, anoxic conditions in microlows).

Soil $\mathrm{P}$ exists in forms of organic $\mathrm{P}$, the fixed mineral $\mathrm{P}$, and orthophosphate (ortho-P). Fixed mineral form of ortho-P is bound to $\mathrm{Al}$ and $\mathrm{Fe}$ oxides/hydroxides (Gunary et al., 1965). The transformation of fixed mineral P into soluble ortho-P is controlled by redox processes (Vepraskas and Faulkner, 2001). As a consequence of reducing conditions in the polygon center, $\mathrm{P}$ bound to $\mathrm{Fe}$ was mobilized, transported, and immobilized in microhighs. Thus, $\mathrm{Fe}$ as well as $\mathrm{P}$ storage was higher in microhighs (PG1, $11.7 \mathrm{~kg} \mathrm{Fe}_{\mathrm{t}} \mathrm{m}^{-2}, 320 \mathrm{mg} \mathrm{P}_{\mathrm{t}}$ $\mathrm{m}^{-2}$ ) than in microlows (PG1, $3 \mathrm{~kg} \mathrm{Fe}_{\mathrm{t}} \mathrm{m}^{-2}, 101 \mathrm{mg} \mathrm{P}_{\mathrm{t}}$ $\mathrm{m}^{-2}$ ) (Table 2).

In addition to the interpedon (center to rim, Fig. 5d), an intrahorizon/pedon upward-translocation (Fig. 5c) was assumed. Distribution of pedogenetic oxides at the polygon rims are typical for gleyzation processes (Schlichting, 1973) and are in agreement with observed $E_{H}$ gradients. The transmission zone of an oxic/anoxic environment, verified by the use of Dpd, was characterized by enrichment of Mn and Fe (Table 1).

More frequent than upward transport of the liquid phase, the ionic migration during refreezing of the active layer in autumn (Fig. 5e) was described in literature (Chuvilin et al., 1998a, 1998b). Controlling factors of this mechanism are temperature gradients (Hinkel and Outcalt, 1994) that promote upward moisture and ionic transfers. As a result of decreasing air temperature in autumn, the heat flux is directly outward, cooling the active layer from above. A downward-moving freezing front evolves, which is delayed by increases in soil water contents or by water transport to the freezing front (Boike, 1997). Consequently, the polygon rim with lower water content and latent heat initially freezes somewhat faster than the water saturated polygon center. Thus, an upward water and ionic transport from the saturated center to the frozen polygon rim via unfrozen water films is enforced.

\section{CONCLUSIONS}

Low-centered polygons are one kind of a typical form of pattern ground in the arctic tundra, which can be divided topographically into microhighs (rims and slopes of the polygon) and microlows (polygon center). The controlling factors of their formation are cryogenetic processes reflected by twisted and mixed soil horizons within elevated parts of the relief. This solid soil phase transloca- tion as well as liquid phase translocation, accompanied by element redistribution, is a result of the complex interplay of thermal, hydraulic, and redox gradients. The strongly varying soil-climatic conditions within the microrelief of polygons determine the direction of gradient (downward vs. upward). Importance of the different transport processes could not be differentiated.

Element redistribution along redox gradients, a phenomenon of which scarce information is provided in literature, was examined. Topography was closely linked to hydrology and the oxidation-reduction environment. Within the microrelief, each unit corresponded via solution fluxes with other units. This linkage was a fundamental part of the catena concept, based on the principles of mobilization, transport and immobilization (Sommer and Schlichting, 1997). Based on saturated/reducing conditions, soils in depressions were deemed as mobilization areas. Element transport was due to (hydro)geochemical gradients. Immobilization of elements was caused by drastic changes in environmental conditions (anaerobic to aerobic milieu). For future research, this upward transport should be validated using radioactive labeled elements. Although the presented study adds to the understanding of element redistribution processes in arctic soils, it does not imply these soils have been sufficiently investigated. All relevant factors of redistribution should be correlated, depending on seasonal and annual range of the permafrost table. This presupposes a long-term investigation to monitor climate, water balance, redox conditions and element migration.

\section{ACKNOWLEDGMENTS}

The authors thank M. Sommer, H. Jungkunst, and P.P. Overduin for helpful comments and critical review of the manuscript as well as Susanne Kopelke for technical assistance. Furthermore, the authors thank the Alfred Wegener Institute for Polar and Marine Research for organization, logistic and financial support of the expeditions 'Lena 1999' and 'Lena 2000'. The research was partly financed by the German Ministry of Science and Technology (System Laptev-See 2000, 03G0534G).

\section{REFERENCES}

Akhmadeeva, I., H. Becker, K. Friedrich, D. Wagner, E.-M. Pfeiffer, W. Quass, M. Zhurbenko, and E. Zöller. 1999. Investigation site 'Samoylov'. p. 19-21. In V. Rachold (ed.) Expeditions in Siberia in 1998. Rep. on Polar Res. 315. Alfred-Wegener-Institut, Bremerhaven, Germany.

Alexander, V., and D.M. Schell. 1973. Seasonal and spatial variation 
of nitrogen fixation in Barrow, Alaska, Tundra. Arct. Alp. Res. 5: $77-88$.

Are, F., and E. Reimnitz. 2000. An overview of the Lena River Delta setting: Geology, tectonics, geomorpholgy, and hydrology. J. Coastal Res. 16:1083-1093.

Arndt, J.L., and J.L. Richardson. 1989. Geochemistry of hydric soil salinity in a recharge-throughflow-discharge prairie-pothole wetland system. Soil Sci. Soc. Am. J. 53:848-855.

Aselmann, I., and J. Crutzen. 1989. Global distribution of natural freshwater wetlands and rice paddies, their net primary productivity, seasonality and possible methane emissions. J. Atmos. Chem. 8: 307-358.

Bartlett, R.J., and B.R. James. 1995. System for categorizing soil redox status by chemical field testing. Geoderma 68:211-218.

Beyer, L., C. Sorge, H.-P. Blume, and H.R. Schulten. 1995. Soil organic matter composition and transformation in Gelic Histosols of coastal continental Antarctica. Soil Biol. Biochem. 27:1279-1288.

Beyer, L., K. Pingpank, G. Wriedt, and M. Bölter. 2000. Soil formation in coastal continental Antarctica (Wilkes Land). Geoderma 95:283304.

Bleich, K., and K. Stahr. 1978. Ein Eisen-Bändchen-Stagnogley in der Bodengesellschaft der mittleren Arktis Kanadas. Eiszeitalter und Gegenwart 28:179-188.

Bliss, L.C. 1997. Arctic ecosystems of North America. p. 541-686. In F.E. Wielgolaski (ed.) Polar and Alpine Tundra. Ecosystems of the world 3. Elsevier, Amsterdam.

Bockheim, J.G., and C. Tarnocai. 1998. Recognition of cryoturbation for classifying permafrost-affected soils. Geoderma 81:281-293.

Bockheim, J.G., L.R. Everett, K.M. Hinkel, F.E. Nelson, and J. Brown. 1999. Soil organic carbon storage and distribution in Arctic Tundra, Barrow, Alaska. Soil Sci. Soc. Am. J. 63:934-940.

Bockheim, J.G., K.M. Hinkel, and F.E. Nelson. 2003. Predicting carbon storage in Tundra soils of Arctic Alaska. Soil Sci. Soc. Am. J. 67:948-950.

Boike, J. 1997. Thermal, hydrological and geochemical dynamics of the active layer at a continuous permafrost site, Taymyr Peninsula, Siberia. Rep. on Polar Res. 242:1-67.

Boike, J., K. Roth, and P.P. Overduin. 1998. Thermal and hydraulic dynamics of the active layer a continuous permafrost site (Taymyr Peninsula, Siberia). Water Resour. Res. 34:355-365.

Böttcher, J., and O. Strebel. 1988. Ermittlung des Redoxpotentials (Eh-Wert) von Böden und Grundwässern aus dem zeitlichen Verlauf der Elektrodendepolarisation. Z. Pflanzenernaehr. Bodenkd. 151:363-368.

Brown, J.1967. Tundra soils formed over ice wedges, Northern Alaska. Soil Sci. Soc. Am. Proc. 31:686-691.

Clark, M.H., and C.-L. Ping. 1997. Hydrology, morphology, and redox potentials in four soils of South Central Alaska. p. 113-131. In M.J. Vepraskas and S.W. Sprecher (ed.) Aquic conditions and hydric soils: The problem soils. SSSA Spec. Publ. No. 50. SSSA, Madison, WI.

Christensen, T.R.S., S. Jonasson, T.V. Callaghan, and M. Havström. 1995. Spatial variation in high-latitude methane flux along a transect across Siberian and European tundra environments. J. Geophys. Res. 100:21035-21045.

Chuvilin, E.M., E.D. Ershov, and N.S. Naletova. 1998a: Ionic migration in frozen soils and ice. p. 167-171. In A.G. Lewkowicz and M. Allard (ed.) Permafrost. 7th Int. Conf. of Permafrost. 23-27 June 1998. Yellowknife, Canada. Collection Nordicana, Univ. Laval., Québec.

Chuvilin, E.M., E.D. Ershov, and O.G. Smirnova. 1998b: Mass transfer and structure formation in freezing. p. 173-179 In Proc. 7th Int. Conf. of Permafrost. Yellowknife, Canada.

Douglas, L.A., and J.C.F. Tedrow. 1960: Tundra soils of arctic Alaska. p. 291-304. In Trans. 7th Int. Cong. Soil Sci. Madison, Vol. 4, Com. V.

Everett, K.R., and J. Brown. 1982. Some recent trends in the physical and chemical characterization and mapping of tundra soils, arctic slope of Alaska. Soil Sci. 133:264-280.

Everett, K.R., and R.J. Parkinson. 1977. Soil and landform associations, Prudhoe Bay area. Alaska. Arct. Alp. Res. 9:1-19.

Farrell, R.E., G.D.W. Swerhone, and C. Van Kessel. 1991. Construction and evaluation of a reference electrode assembly for use in monitoring in situ soil redox potentials. Commun. Soil Sci. Plant Anal. 22:1059-1068.

Feustel, I.C., A. Dutilly, and M.S. Anderson. 1939. Properties of soils from North American arctic region. Soil Sci. 48:183-199.

Fiedler, S. 1997. In-situ-Langzeitmessungen des Redoxpotentials in hydromorphen Böden einer Endmoränenlandschaft im württembergischen Alpenvorland. Hohenheimer Bodenkdl. Hefte 42:1-135.

Gersper, P.L., V. Alexander, and S.A. Barkley. 1980. The soils and their nutrients. p. 219-254. In J. Brown (ed.) An arctic ecosystem. The coastal tundra at Barrow, Alaska. Hutchinson and Ross. Stoudsburg Dowden.

Grulke, N.E., G.H. Riechers, W.C. Oechel, U. Hjelm, and C. Jaeger. 1990. Carbon balance in tussock tundra under ambient and elevated atmospheric $\mathrm{CO}_{2}$. Oecologia 83:485-494.

Gunary, D., E.G. Hallsworth, and D.V. Crawford. 1965. The experimental study of the mobility of ions in soils, with particular reference to phosphorus. p. 149-156. In E.G. Hallworth and D.V. Crawford ed. Experimental pedology. Butterworths, London.

Haag, R.W. 1974. Nutrient limitations to plant production in two tundra communities. Can. J. Bot. 52:103-116.

Hallsworth, E.G., J.A. Beattie, and W.E. Darley. 1982. Formation of soils in an aridic environmental western New South Wales, Australia. Catena (suppl.) 1:83-102.

Harris, R., K. Bartlett, S. Frolking, and P. Crill. 1993. Methane emission from northern high-latitude wetlands. p. 449-485. In R.S. Oremland (ed.) Biogeochemistry of global change. Chapman and Hall, New York.

Hinkel, K.M., and S.I. Outcalt. 1994. Identification of heat transfer processes during soil cooling, freezing and thaw in central Alaska. Permafrost and Periglacial Proc. 5:217-235.

ISSS-ISRIC-FAO. 1998. World reference base for soil resources. FAO, World Soil Resources Rep. No. 84, Rome.

John, M.K. 1970. Colorimetric determination of phosphorus in soil and plant material with ascorbic acid. Soil Sci. 109:214-220.

Kellog, C.E. 1934. Morphology and genesis of the Solonetz soils of western North Dakota. Soil Sci. 38:483-501.

Korotaev, V.N. 1986. Geomorphology of river deltas on the Arctic coast of Siberia. Polar Geography Geol. 10:139-147.

Kutzbach, L. 2000. Die Bedeutung der Vegetation und bodeneigener Parameter für die Methanflüsse in Permafrostböden. Master Thesis, University of Hamburg, Institute of Soil Science.

Lundin, L.-C., and H. Johnsson. 1994. Ion dynamics of a freezing soil monitored in situ by time domain reflectometry. Water Resour. Res. 30:3471-3478.

MacLean, A.H., and S. Pawluck. 1975. Soil genesis in relation to groundwater and soil moisture regimes near Vegreville, Alberta. Can. J. Soil Sci. 26:278-293.

McCown. B.H. 1978. The interactions of organic nutrients, soil nitrogen, and soil temperature and plant growth and survival in the arctic environment. p. 435-456. In L.L. Tieszen (ed.) Vegetation and Production Ecology of an Alaskan Arctic Tundra. Ecological Studies 29. Springer. New York.

Mehra, O.P., and M.L. Jackson. 1960. Iron oxide removal from soils and clays. Clays Clay Miner. 7:317-327.

Michaelson, G.J., C.L. Ping, and J.M. Kimble. 1996. Carbon storage and distribution in tundra soils of Arctic Alaska, USA. Arct. Alp. Res. 28:414-424.

Mueller, K. 1997. Oberflächenstrukturen und Eigenschaften von Permafrostböden im nordsibirischen Lena-Delta. Z. Pflanzenernaehr. Bodenkd. 160:497-503.

Oechel, W.C., S.J. Hastings, M. Jenkins, G. Riechers, N.E. Grulke, and G.L. Vourlitis. 1993. Recent change of arctic tundra ecosystems from a net carbon sink to a source. Nature. 361:520-526.

Overduin, P.P., and K.L. Young. 1997. The effect of freezing on soil moisture and nutrient distribution at Levinson-Lessing Lake, Taymyr Peninsula, Siberia. p. 327-333. In I.K. Iskandar et al. (ed.) International Symposium on Physics, Chemistry, and Ecology of Seasonally Frozen Soils. Special Report 97-10. Fairbanks, Alaska.

Pfeiffer, E.-M., I. Akhmadeeva, H. Becker, K. Friedrich, D. Wagner, W. Quass, M. Zhurbenko, E. Zöllner, J. Boike, D.V. Solovieva, and V.I. Pozdnyakov. 2000. Modern processes in permafrost affected soils. p. 22-36. In V. Rachold and M.N. Grigoriev (ed.) Russian-German Cooperation System Laptev Sea 2000: The Expe- 
dition LENA 1999. Rep. on Polar Res. 354. Alfred-Wegener-Institut, Bremerhaven, Germany.

Rachold, V., and M.N. Grigoriev. 2001. Russian-German cooperations system Laptev Sea 2000: The Lena Delta 1998 expedition. Rep. Polar Res. 388:1-135.

Rachold V., and M.N. Grigoriev. 2000. Russian-German cooperation system Laptev Sea 2000. The Lena Delta 1998 Expedition. Rep. Polar Res. 315:1-269

Rachold, V., and M.N. Grigoriev. 1999. Russian-German cooperation system Laptev Sea 2000: The Lena Delta 1998 Expedition. Rep. Polar Res. 315:1-259.

Richardson, J.L., J.L. Arndt, and J.A. Montgomery. 2001. Hydrology of wetland and related soils. p. 35-84. In J.L. Richardson and M.J. Vepraskas (ed.) Wetland soils. Genesis, hydrology, landscape and classification. Lewis Publishers. Boca Raton, FL.

Rieger, S. 1983. The genesis and classification of cold soils. Academic Press, New York

Schachtschabel, P., H.-P. Blume, G. Brümmer, K.-H. Hartke, and U. Schwertmann. 1998. Lehrbuch der Bodenkunde. 14th ed. Enke, Stuttgart.

Schlichting E., H.P. Blume, and K. Stahr. 1995. Bodenkundliches Praktikum. Eine Einführung in pedologische Arbeiten für Ökologen, insb. Land-und Forstwirte, und für Geowissenschaftler. Blackwell, Berlin.

Schlichting, E. 1973. Pseudogleye und Gleye-Genese und Nutzung hydromorpher Böden. p. 1-6. In E. Schlichting and U. Schwertmann (ed.) Pseudogley \& Gley. Trans. Comm. V and VI Int. Soc. Soil Sci., Verlag Chemie, Weinheim.

Schüller, H. 1969. Die CAL-Methode, eine neue Methode zur Bestimmung des pflanzenverfügbaren Phosphates in Böden. Z. Pflanzenernaehr. Bodenkd. 123:48-63.

Schwamborn, G., V. Rachold, and M.N. Grigoriev. 2002. Late quaternary sedimentation history of the Lena Delta. Quat. Int. 89:119134.

Schwertmann, U. 1964. Differenzierung der Eisenoxide durch Extraktion mit Ammoniumoxalat-Lösung. Z. Pflanzenernaehr. Bodenkd. 101:194-202.

Soil Survey Staff. 1999. Soil Taxonomy - A basic system of soil classification for making and interpreting soil surveys. 2nd ed., U.S. Gov. Print. Office, Washington, DC.

Sommer, M., and E. Schlichting. 1997. Archetypes of catenas in respect to matter-A concept for structuring and grouping catenas. Geoderma 76:1-33.

Sommer, M., H. Thies, E. Kolb, H. Bächle, and K. Stahr. 1997. Bio- geochemistry of a cirque-lake landscape: An interdisciplinary study in a catchment of the northern Black Forest, Germany. Water Resour. Res. 33:2129-2142.

Steinwand, A.L., and J.L. Richardson. 1989. Gypsum occurrence in soils on the margin of semi permanent prairie pothole wetlands. Soil Sci. Soc. Am. J. 53:836-842.

Tarnocai, C., and S.C. Zoltai. 1978. Earth hummocks of the Canadian arctic and subarctic. Arct. Alp. Res. 10:581-594.

Tedrow, J.C.F., J.V. Drew, and L.A. Douglas. 1958. Major genetic soils of the Arctic Slope of Alaska. J. Soil Sci. 9:33-45.

Tedrow, J.C.F. 1977. Soils of the polar landscapes. Rutgers University Press, New Brunswick, New Jersey.

Vepraskas, M.J., and S.P. Faulkner. 2001. Redox chemistry of hydric soils. p. 85-105. In J.L. Richardson and M.J. Vepraskas (ed.) Wetland soils. Genesis, hydrology, landscape and classification. Lewis Publishers. Boca Raton, FL.

Van Vliet-Lanoë, B. 1991. Differential frost heave, load casting and convection: Converging mechanisms; a discussion of the origin of cryoturbations. Permafrost Periglac Process. 2:123-139.

Von Zezschwitz, E., U. Schwertmann, and B. Ulrich. 1973. Die Podsolierungsstadien von Braunerden aus Schieferschutt. Z. Pflanzenernähr. Bodenkd. 136:40-52.

Wagner, D., A. Kurchatova, and G. Stoff. 2001a. Modern processes in permafrost affected soils. p. 16-23. In V. Rachold and M.N. Grigoriev (ed.) Russian-German Cooperation System Laptev Sea 2000. The Expedition LENA 2000. Rep. on Polar Res. 388. AlfredWegener-Institut, Bremerhaven, Germany.

Wagner, D., E. Spieck, E. Bock, and E.-M. Pfeiffer. 2001b. Microbial life in terrestrial permafrost: Methanogenesis and nitrification in Gelisols as potentials for exobiological processes. p. 143-159. In G. Horneck and C. Baumstark-Khan (ed.) Astrobiology: The quest for the conditions of life. Springer-Verlag, New York.

Wagner, D., S. Kobabe, E.-M. Pfeiffer, and H.-W. Hubberten. 2003. Microbial controls on methane fluxes from a polygonal tundra of the Lena Delta, Siberia. Permafrost Periglac. Process. 14:173-185.

Washburn, A.L. 1979. Geocryology. A survey of periglacial processes and environments. Arnold, London.

Wein, N. 1999. Sibirien. Perthes Regional profile. Klett-Perthes, Gotha

Whittig, L.D., and P. Janitzky. 1963. Mechanisms of formation of sodium carbonate in soils I. manifestations of biologic conversions. J. Soil Sci. 14:322-333.

Wiegand, C.L., L. Lyles, and D.L. Cater. 1966. Interspersed saltaffected and unaffected dryland soils of the lower Rio Grande Valley: II. Occurrence of salinity in relation to infiltration rates and profile characteristics. Soil Sci. Soc. Am. Proc. 30:106-110. 